\title{
VIDAS TRANSITÓRIAS. ENTRE OS COCAIS MARANHENSES E OS CANAVIAIS PAULISTAS
}

\section{Transitory Lives. Between the Forests of Maranhão and Sugarcane of São Paulo}

Prof. ${ }^{\text {a }}$ Dr ${ }^{\mathrm{a}}$. Maria Aparecida de Moraes Silva

Universidade do Estado de São Paulo - PP

Rodovia Washington Luiz, Km 235, CEP: 13560-000 - Sao Carlos, SP - Brasil

Tel:: (+55 16) 33518673 - maria moraes@terra.com.br

\section{$a a a_{a a}$}

\begin{abstract}
Resumo
O objetivo deste texto é a análise das redefinições sociais e laborais do processo migratório de milhares de camponeses do estado do Maranhão, situado no nordeste do Brasil, para o trabalho nos canaviais do estado de São Paulo. Este processo é resultante da expropriação havida na última década nesta região. A análise visa também a compreensão da migração temporária enquanto processo envolvendo aqueles que partem - homens, adultos e jovens - e aqueles que ficam -os membros das famílias. O universo empírico da investigação se concentrou em duas cidades de origem dos migrantes -Timbiras e Codó, situadas no sudeste do estado do Maranhão - e na região de destino de Ribeirão Preto, considerada o maior pólo produtor de açúcar é álcool do país. A metodologia empregada baseou-se na história oral, por meio da coleta de depoimentos, registros imagéticos e fontes escritas, basicamente, processos jurídicos movidos pelos camponeses que foram expropriados.
\end{abstract}

Palavras-chave: Campesinato, migrações, trabalho assalariado.

\begin{abstract}
The objectify of this text is the analysis of the process migrant of peasants from state Maranhão/Brazil to the labor in the sugar cane of state São Paulo. This process results from expropriation in the last decade in this region. The analysis pretends the study the temporary migration as process of family's members that migrant and they that stay there. The universe of the research is the cities Timbiras and Codó (Maranhão) and Ribeirão Preto (São Paulo). The methodology is based in the oral history, documents and photos.
\end{abstract}

Key Word: Peasants, process migrant, labor.

\section{Resumen}

El objetivo de este texto es analizar las redefiniciones sociales y laborales del proceso migratorio de miles de campesinos del estado de Maranhão, situado en el nordeste de Brasil, para el trabajo en los cañaverales del estado de São Paulo. Este proceso es resultante de la expropiación habida en la última década en el nordeste brasileño. El análisis también se propone comprender la migración temporaria como proceso, envolviendo aquellos que parten - hombres, adultos y jóvenes - y aquellos que se quedan -los miembros de las familias. El universo empírico de la investigación se concentró en dos ciudades de origen de los migrantes -Timbiras y Codó, situadas en el sudeste del estado de Maranhão -, y en la región de destino de Riberão Preto, considerada el mayor polo productor de azúcar y alcohol del país. La metodología empleada se basó en la historia oral, por medio de la recolección de testimonios, registros imagéticos y fuentes escritas, básicamente, procesos judiciales levantados por los campesinos que fueron expropiados.

Palabras Clave: Campesinos, proceso migratorio, trabajo.

\section{$a \boldsymbol{a}_{a a}$}

Revista da ANPEGE, v. 7, n. 1, número especial, p. 161-178, out. 2011.

ISSN 1679-768 X @ 2003, Associação Nacional de Pesquisa e Pós-Graduação em Geografia. Todos os direitos reservados. 


\section{INTRODUÇÃO}

O estado de São Paulo é reconhecido como o mais desenvolvido do Brasil não somente pelo fato de concentrar grandes indústrias, como também grandes empresas agropecuárias, sobretudo as de produção de açúcar e álcool, tal como pode ser visto na figura 1. Atualmente, este estado concentra dois terços da área ocupada com cana no país, o que corresponde a mais de 4 milhões de hectares. O desenvolvimento econômico desta região data do início do século passado, quando a economia cafeeira e a criação de várias indústrias fortaleceram a acumulação do capital, no campo e nas cidades.

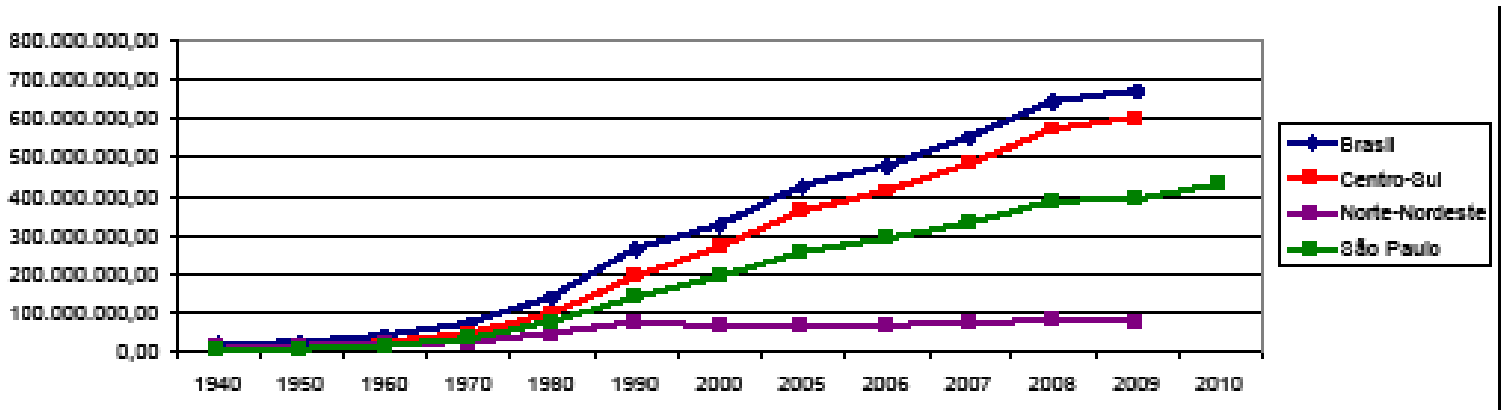

Figura 1 - Quantidade produzida de cana (tonelada) - 1940 a 2010

Fonte: Censo Agropecuário do IBGE (1940, 1950, 1960, 1970, 1980). Pesquisa Agrícola Municipal do IBGE (1990, 2000, 2005, 2006, 2007, 2008, 2009). Instituto de Economia Agrícola (2010). Elaborado por Beatriz Medeiros de Melo.

Nos limites deste texto, não objetivamos a análise histórica deste desenvolvimento. Nossa proposta se restringe à situação social e laboral dos trabalhadores migrantes temporários que se destinam para o estado de S. Paulo, particularmente, a região de Ribeirão Preto, que atualmente concentra as maiores usinas de açúcar e álcool do país, e já está sendo conhecida mundialmente como a capital do ouro verde (etanol).

Desde o século passado, a economia agrária do estado e desta região, em particular, contou com a presença de trabalhadores migrantes nacionais para o trabalho nas lavouras de café, de cana-de-açúcar, laranja e outras. Na década de 1960, houve a intensificação do processo de modernização da agricultura paulista por meio da modernização do processo produtivo. Data desta época o surgimento de grandes usinas de açúcar e álcool, as quais foram beneficiadas pelo Proálcool, em 1975, durante o governo da ditadura militar. No que tange ao Proálcool, tratou-se de um Programa que recebeu vultosos incentivos financeiros e teve seu auge em meados da década de 1980. Por meio destes incentivos, o setor canavieiro se transformou numa agroindústria avançada, incorporando tecnologia no plantio e nas usinas. A produção de automóveis, movidos a álcool foi a grande mola propulsora deste programa. A partir de então, cada vez mais, as fábricas de automóveis incentivarão a mistura do álcool à gasolina até chegarem a 2003, quando surgiram os automóveis flex fuel movidos a álcool ou gasolina. No entanto, este processo de modernização e reestruturação produtiva foi seguido do processo de expulsão de milhares de trabalhadores residentes nas fazendas: colonos, parceiros, pequenos arrendatários, posseiros e sitiantes. No período de 1960 a 1980, saíram da área rural do estado mais de 2,5 milhões de pessoas Além do processo de expulsão, que culminou no desmantelamento do processo de trabalho assentado no sistema dos trabalhadores permanentes, fixos, residentes nas fazendas, e sua transformação em "bóias-frias", a modernização da agricultura, sob a égide do Estado brasileiro, foi responsável pelo surgimento das chamadas migrações temporárias, caracterizadas pela presença de milhares de pessoas, geralmente provenientes de áreas pobres do país, que foram obrigadas, pela falta de condições de sobrevivência, a se deslocar para as áreas mais ricas, em busca de trabalho. A região de Ribeirão Preto, a partir da década de 1960 transformou-se num pólo receptor de milhares 
destes migrantes todos os anos, que se empregam nas lavouras de café, no corte da cana e também na colheita da laranja. Na verdade, trata-se de uma migração permanentemente temporária, pois a grande maioria deles migra todos os anos tendo suas vidas divididas no espaço e no tempo. Assim a partir do mês de abril chegam à região de Ribeirão Preto migrantes provenientes do Vale do Jequitinhonha/Minas Gerais, interior da Bahia e dos demais estados do nordeste, inclusive do Maranhão e Piauí. No início do mês de novembro, regressam às suas regiões, para, novamente, reiniciarem o ciclo migratório no próximo ano. Em razão das inúmeras migrações que, muitas vezes, não se destinam para os mesmos lugares, as vidas desses trabalhadores assemelham-se àquelas do vôo das andorinhas, que partem em busca de alimentação e melhores condições climáticas, retornando ao local de origem, assim que a sobrevivência seja garantida. (SILVA (1991); MARTINS (1988).

A grande transformação econômica caracterizada pela modernização da agricultura se iniciou durante os governos da ditadura militar. As leis produzidas entre 1964 a 1983 resultaram num processo vertiginoso de expulsão do campesinato em todas regiões do país. No Vale do Jequitinhonha em Minas Gerais, de onde se originaram e ainda hoje se originam milhares de migrantes sazonais para a região de Ribeirão Preto, houve a expropriação das terras dos camponeses, as quais foram vendidas a grandes empresas de reflorestamento. Milhares de camponeses expropriados passaram a migrar temporariamente para São Paulo e outras regiões do país. Na década de 1970, mais de duzentas mil pessoas migraram definitivamente desta região.

Quanto às origens geográficas dos migrantes neste período, além do Vale do Jequitinhonha, outras serviram como grandes celeiros desta mão-de-obra. Cabe mencionar o Norte do Paraná, responsável pela expulsão de milhares de pequenos proprietários, parceiros e colonos, em virtude do processo vertiginoso de modernização da agricultura, principalmente, a partir dos anos de 1970. De acordo com dados do Censo Demográfico, no Estado do Paraná, houve a diminuição da população rural residente de 4.425 .490 pessoas para 3.156 .831 , no período de $1970-80$, o que significa um decréscimo em torno de quase, 1.300 .000 pessoas. Em 1995, esta população era de 2.440 .000 pessoas. Em relação ao período 1970-95, houve um declínio de 45\%, portanto, quase a metade da população rural. Os dados mostram que estas duas regiões foram as duas grandes fornecedoras desta força de trabalho no período de 1960-1980. No entanto, muitos trabalhadores dos estados do nordeste, em especial do interior da Bahia, também se dirigiram a esta região em busca de trabalho. Segundo um estudo de 1980, a região de Ribeirão Preto recebeu um contingente migratório de 120.030 pessoas neste período que concerne aos efeitos do Proálcool (MOTTA e QUINTEIRO1983). Portanto, além dos migrantes sazonais, houve também a vinda de milhares de pessoas que se fixaram definitivamente nas cidades da região. Em se tratando da migração temporária, torna-se difícil uma quantificação exata. No entanto, dados fornecidos pelo SPM (Serviço Pastoral do Migrante) até 1990, cerca de 40 a 50 mil trabalhadores desta região eram sazonais. Atualmente, para o conjunto do estado em razão da gigantesca expansão dos canaviais, estima-se que há em torno de 200 mil migrantes temporários. Estes dados revelam que as grandes empresas de açúcar e álcool atraíram e continuam atraindo milhares de trabalhadores migrantes de várias partes do país.

\section{A PRESENÇA DE MIGRANTES DO MARANHÃO}

A partir dos finais da década de 1990, no entanto, assiste-se ao processo de mudança da cartografia migratória. Muitos dos migrantes atuais são provenientes do Maranhão e Piauí, estados que, no passado, tinham pouca ou nenhuma participação neste processo e que fazem parte da pré-amazônia (meio norte). Uma das explicações dada para a mudança da cartografia migratória reside no fato de que houve uma enorme intensificação do ritmo do trabalho nos canaviais, traduzida em termos da média de cana cortada, em torno de 12 toneladas diárias. Este fato está diretamente relacionado à capacidade física, portanto, à idade, na medida em que acima de trinta anos de idade, os trabalhadores já encontram mais dificuldades para serem empregados. Desta sorte, a vinda destes outros migrantes cumpre a função de repor, por meio do fornecimento de maior força de trabalho, 
o consumo exigido pelos capitais cuja composição orgânica é maior. Outra explicação se reporta ao processo histórico de expropriação do campesinato desta região, responsável pela produção destes migrantes.

Este campesinato se formou nos finais do século XIX, logo após a abolição dos escravos, quando muitas comunidades de libertos se juntaram aos quilombolas (negros que fugiam das fazendas e desenvolviam uma economia de subsistência, por meio da apropriação coletiva da terra). É neste período que tem início a produção camponesa de ex-escravos chamados caboclos, moradores de grandes latifúndios e também por outros ocupantes de terras, provenientes do nordeste, em virtude das secas. A utilização do babaçu de forma coletiva é conhecida desde então como o período do "coco livre", considerado um produto da natureza, portanto pertencente a todos, segundo o direito consuetudinário. No Maranhão, os camponeses ainda praticam a economia extrativista das florestas de babaçu, uma espécie de palmeira (orbyginia martiana). Do coco, extraem a amêndoa vendida para fins industriais - para a defumação da borracha e combustível - e também utilizada para a produção de azeite para a alimentação; da casca, fazem o carvão empregado para o preparo dos alimentos; da folha da palmeira, fabrica, cestos, chapéus, vassouras, cobrem a casa, construída de adobe (argila). A palmeira tem até 15 metros de altura e chega a produz mais de 500 frutos (coco babaçu) a cada florada Esta floresta abrange no Brasil 18,5 milhões de hectares, dos quais mais da metade se acha no Maranhão. A palavra babaçu, origina-se do tupi wawa'su. Além do Brasil, a palmeira é encontrada na Bolívia, Colômbia e México. A lógica da reprodução deste campesinato se baseou na complementaridade entre agricultura de subsistência e coleta do coco babaçu, segundo uma divisão sexual do trabalho bem definida. A coleta é desenvolvida pelas mulheres e a agricultura pelos homens. A atividade de coleta ocorre no período oposto ao da agricultura, de tal modo que quando os alimentos da família se escasseiam, as atividades das mulheres garantem a reprodução, pois além do azeite para o próprio consumo, as amêndoas são vendidas para diversos fins industriais, desde o final da Primeira Guerra Mundial (Antunes, 2006).

Esta realidade passa a sofrer transformações a partir dos anos de 1970, quando os governos da ditadura militar incentivam a modernização da agricultura por meio de apoio à grandes empresas e proprietários de terra. A partir de então, grandes empresas nacionais e internacionais apossaram de milhares de hectares de terra em várias regiões do país, processo que envolveu conflitos e assassinatos de povos indígenas, caboclos, além de líderes camponeses e religiosos (Martins, 1982; Sader, 1991). No Maranhão, houve a conversão da agricultura de alimentos para a produção de soja e pecuária, destinadas à exportação. Com isso, as terras começam a ser cercadas pelas propriedades privadas e as florestas de babaçu destruídas. Data deste período o início do processo de expropriação dos camponeses, cujo destino passou ser a migração para regiões de garimpo e desflorestamento da Amazônia, muitos dos quais foram e são ainda escravizados.

O estudo de SADER (1991) mostra o caso do projeto de colonização do Maranhão, efetuado pela Companhia Maranhense de Colonização (COMARCO) que abre possibilidade para o início de um longo ciclo de grilagens e expropriações no Estado, agravado pela construção, no início da década de 70, da estrada que liga a cidade de Santa Inês a Açailância, esta última na margem da Belém-Brasília, ao norte de Imperatriz. Os mais diretamente afetados neste processo de expropriação são os descendentes de quilombos que até então se constituíam em pequenos proprietários. Muitos deste passam a migrar, mas, por outro lado, outros também resistem, constituindo bairros negros nas proximidades das terras expropriadas.

Estes fatos estão presentes na memória camponesa, segundo a qual, o coco babaçu que era liberto passou a ser preso, isto é, apropriado pelos grandes proprietários, pondo fim ao livre acesso a um bem natural e transformando o babaçu de valor de uso em valor de troca, em mercadoria, algo que foi motivo de um movimento de resistência de mulheres camponesas da comunidade de Ludovico em meados da década de 1980, graças ao qual, após mais de 10 anos, foi conseguida a aprovação de uma lei no estado do Maranhão, do babaçu livre, que garante a livre coleta do fruto aos camponeses. 
Nos finais da década de 1990 inicia-se a migração de muitos desses expropriados para os canaviais paulistas. Esta migração é essencialmente masculina. Enquanto os homens partem, as mulheres geralmente ficam. Aquelas que ainda residem na área rural cuidam da agricultura de subsistência e são quebradeiras de coco babaçu, atividade desempenhada por algumas que residem nas periferias das cidades. Algumas delas partem com os maridos, e, às vezes, até com os filhos, para lhes preparar a comida e lavar suas roupas. Nas periferias das cidades dormitórios paulistas vivem em minúsculos quartos alugados nos fundos-de-quintais, de onde geralmente saem, à espera dos maridos que trabalham no corte da cana (Vetorassi, 2006; Silva et al., 2006).

Algumas pesquisas recentes oferecem informações sobre os perfis destes migrantes. O relatório de recente pesquisa da Pastoral do Migrante, em parceria com a Comissão Pastoral da Terra do Estado do Piauí - onde houve nas últimas décadas a instalação de grandes fazendas de soja - obteve informações de 367 domicílios familiares de trabalhadores que saem para trabalhar em outros estados, nos municípios considerados como os que possuem os maiores índices de trabalhadores migrantes: Barras, São Miguel, São Raimundo Nonato, União Esperantina e Uruçuí. Das famílias entrevistadas $(74,1 \%$ ) são formadas por 5 membros ou mais; $82,7 \%$ dos membros das famílias realizam trabalhos nas atividades agrícolas. A renda familiar dos entrevistados segundo essa fonte é: $71,8 \%$ dos entrevistados obtêm com o trabalho realizado na própria região declaram que a renda da família não atinge um salário mínimo e das famílias que declaram renda maior que um salário, e $86,9 \%$ possuem aposentados entre seus membros. Estes dados revelam que $93 \%$ dos que saem para trabalhar são homens que se distribuem nas diferentes faixas etárias, sendo que $65,3 \%$ se concentram na faixa entre 18 e 35 anos, idade em que o trabalhador possui maior força física para trabalhos pesados. Os níveis de escolaridade são baixos: 16\% são analfabetos e $45 \%$ não atingiram sequer a quarta série do ensino fundamental.

Em torno de $40 \%$ das famílias têm pelo menos duas pessoas que viajam todos os anos para trabalhar fora; em $90,8 \%$ dos deslocamentos a migração não é definitiva: os trabalhadores vão e voltam demorando entre cinco a sete meses e mais da metade é constituída de chefes de família; $76,6 \%$ dos trabalhadores saíram mais do que duas vezes para trabalharem nos últimos 5 anos. Apenas 11,5\% dispõem de dinheiro para viajar, 56,6\% pedem dinheiro emprestado para familiares ou amigos e 31,9\% recebem adiantamento do gato (arregimentador de mão-de-obra). A dívida contraída com o gato pode representar o início da submissão à escravidão ou ao trabalho degradante, segundo esse levantamento. Quanto à maneira de aliciamento desses trabalhadores, o relatório aponta: $15,6 \%$ dos trabalhadores saem sós quando vão trabalhar em outro local; 48,4\% migram em pequenos grupos com parentes ou colegas e 56,0\% saem em grupos grandes que são aliciados por gatos. O primeiro contato do gato é feito nos lugarejos, geralmente nos bares "boteco", entre um gole e outro de cachaça, ou com alto falante em cima do carro até o anúncio nas rádios locais. Prometendo bons salários, que variam entre R $\$ 800.00$ e R $\$ 1.200 .00$ por mês, alojamentos bons com comida, lavadeira de roupa de graça e que no final da safra a usina dará o seguro desemprego. O segundo passo é o transporte que, na maioria das vezes, é feito por empresas clandestinas, que na saída, o "gato" oferece ao trabalhador, cachaça, muitas mulheres em volta do ônibus e outras coisas e partem do município geralmente de madrugada, utilizam as estradas vicinais ou até estradas de terra, não trafegando pelas BRs, devido a fiscalização da Policia Rodoviária Federal. (Comissão Estadual de Prevenção e Combate ao Trabalho Escravo (CPTE); CPT/PI; PETAG/PI - PASTARAL DO MIGRANTE/PI e DRT/PI. APOIO: OIT-Brasil.Em 2000, apenas 100 trabalhadores destes dois estados migraram para S. Paulo; em 2007, segundo estimativas da pastoral do Migrante, este número passou para 7.000 .

Um outro levantamento recente foi feito no município de Timbiras/MA, onde 54\% dos chefes de família entrevistados nos bairros periféricos possuíam terras arrendadas, 16\% terras próprias e $15 \%$ posses. A forma de pagamento no sistema de arrendamento é uma saca de arroz em palha para cada linha de roça, que corresponde a 0,3ha de terra (Carneiro, 2005). Das 114 famílias entrevistas, $71(63 \%)$ possuem algum membro trabalhando fora do município de Timbiras. Quanto á faixa etária, 
esta pesquisa constatou que 57\% dos migrantes tinham entre 19 e 34 anos, portanto, uma força de trabalho de homens ainda jovens.

Quanto à ocupação, 53,5\% dos entrevistados responderam que o chefe da família tem por ocupação principal a agricultura, enquanto $20 \%$ sobrevivem principalmente com os rendimentos oriundos da aposentadoria rural. Do total dos ocupados na agricultura, 54\% dos entrevistados trabalham em terras arrendadas, $16,4 \%$ em terras próprias e $15 \%$ em posses. A forma de pagamento pelo arrendamento corresponde a um saco de $60 \mathrm{~kg}$ de arroz (em palha) por cada linha de roça plantada, ou seja, 0,33 hectares.

Quanto ao tempo de moradia, na periferia de Timbiras, esta pesquisa revela que, para 20,2\% das famílias entrevistadas, o tempo de residência na moradia atual é entre 0 a 2 anos; para 12,3\% de 3 a 5 anos, para 22,8\% de 6 a 10 anos, enquanto $42,1 \%$ responderam estar lá residindo há mais de 10 anos. Baseando-se em dados do IBGE, sobre a estrutura agrária do município, o autor conclui que o processo de expropriação do campesinato maranhense tem ocorrido graças à ação de grandes empresas, com apoio da SUDENE, SUDAM e fundos setoriais como o FISET, responsáveis pelo incremento do reflorestamento e pela redução incessante da área da produção camponesa, que, apesar de representarem em torno de $92 \%$ do número de estabelecimentos com até 50 hectares, ocupam apenas $6,8 \%$ da área total. Este fato contribui para o empobrecimento dos membros da família camponesa, obrigando-os a migrarem em busca de meios de sobrevivência. No município de Timbiras, 44,7\% das famílias entrevistadas são assistidas pelos recursos dos programas do governo federal, como Bolsa-escola, Bolsa-família, PETI e Vale-gás.

\section{VIOLÊNCIA E EXPULSÃO DOS CAMPONESES}

A fim de aprofundar o conhecimento desta realidade migratória, realizamos uma pesquisa no início de 2007 em duas cidades do Maranhão - Timbiras e Codó -. Além da coleta de vários depoimentos com homens, mulheres e crianças, analisamos 85 processos jurídicos movidos por camponeses que foram expulsos de suas terras por meio do uso da violência e ameaças de morte, muitos dos quais passaram a viver nas periferias destas duas cidades. Muitos membros destas famílias não tiveram outra alternativa senão aquela da migração para os canaviais paulistas, além de outras regiões do país. A pesquisa sobre as crianças que possuíam algum membro da família migrante, referiu-se à coleta de desenhos por meio de suas representações sobre suas famílias e sobre "Ribeirão" (região de Ribeirão Preto em S. Paulo). Nosso objetivo era captar a realidade migratória sob a ótica das crianças da 4 a série do ensino primário.

Analisando os processos jurídicos movidos por 85 camponeses expropriados em 2004 nos municípios de Coroatá, Timbiras e Codó, constata-se o seguinte. Estas famílias eram constituídas de moradores que pagavam a renda em produto ao dono da terra. Plantavam arroz, feijão, milho, mandioca e frutas. Além disso viviam da economia extrativista do coco babaçu, atividade, essencialmente desenvolvida pelas mulheres, segundo a tradição do campesinato desta região. Viviam em casas de adobe (argila) cobertas de folhas da palmeira do babaçu.

No ano de 2004, homens armados desalojaram 100 famílias da Fazenda São Raimundo, pertencente a José Ribamar Thomé. Os homens eram mandantes de Ricardo Reis Vieira, que, por intermédio de escrituras falsas, afirmava ser o legítimo proprietário da terra. Segundo os autos:

O Reclamado, Ricardo reis Vieira, valendo-se de seu poderio econômico, inclusive comandando homens armados, invadiu as terras de José Ribamar Thomé, nas quais o Reclamante e sua família trabalhavam, expulsou delas mais de 100 famílias, queimou mais de 100 casas, expulsou os trabalhadores e se apossou indevidamente de parte da fazenda ; isso causou sérios danos materiais e morais aos trabalhadores, que passaram a viver na periferia das cidades de região, em casa de parentes. 
Segundo os relatos de camponeses, a queima das casas foi feita pela Empresa do Grupo Maratá, que possui negócios relacionados ao comércio, agricultura e indústria no nordeste. No Maranhão, esta empresa possui extensas áreas com pecuária.

O depoente informa que o incêndio começou por volta das 16 hs e que os executores ordenaram que os camponeses retirassem suas coisas de dentro das casas, caso contrário, seriam queimadas; queimaram, galinhas, porcos, ovelhas e também as plantações de arroz e mandioca. O depoente informa também que o objetivo era deixar a área limpa para a plantação de capim para o gado desta empresa do Grupo Maratá.

No processo judicial N.223/2006 (Fórum de Timbiras/Maranhão), constam as fotos das casas queimadas. Os camponeses não resistiram a este ato de violência, pois caso em contrário, seriam mortos, segundo vários depoimentos. Muitos ainda não recorreram à justiça em razão do medo de represálias por parte da empresa expropriadora. Esta realidade concreta se insere na história do capitalismo no campo no Brasil que sempre foi acompanhada de violência, inclusive nos dias atuais (CPT. Conflitos no campo. Vários anos). Este processo se caracteriza pela acumulação primitiva, que corresponde à pré-história do capital, e também em determinadas realidades histórico-sociais pode ocorrer simultaneamente ao processo de acumulação mais avançado. Este é o caso do capitalismo no Brasil, cujas desigualdades regionais formam parte de um único processo.

Ademais da expropriação, a empresa destruiu as florestas de babaçu por meio de máquinas e do fogo. Em seguida, foi semeado capim para o gado. Este fato foi mais um agravante da situação dos camponeses expropriados nas periferias das cidades, pois a única forma de sobrevivência é garantida pelo trabalho das mulheres que ainda continuaram exercendo a coleta do coco.

\section{OS TERRITÓRIOS MIGRATÓRIOS ENQUANTO PROCESSOS SOCIAIS}

Acreditamos que esta análise do processo histórico, responsável pela produção destes proletários, é necessária ao desenvolvimento de nossas inflexões sobre as implicações sociais e laborais desta migração para os canaviais paulistas. Em outros termos, estes dados históricos nos possibilitam a compreensão da migração sob a ótica dos sujeitos envolvidos nos processos migratórios no contexto de estruturas sociais determinadas historicamente. Partimos da idéia de Marx, segundo a qual, os sujeitos fazem a história, porém em condições determinadas. Logo, as estruturas objetivas - classe, gênero, raça/etnia - são as organizações sociais, no interior das quais as ações dos sujeitos migrantes se desenrolam. Consideramos o migrante sob duas óticas: inicialmente, trata-se de um (a) trabalhador (a) produzido no bojo de determinadas relações sociais, resultantes de processos de violência e expropriação. O migrante acha-se inserido numa realidade social, definida por laços sociais (familiares, grupos de vizinhança, valores, ideologias etc.), que o caracterizam como pertencente a um determinado espaço social e cultural. Portanto, a denominação abstrata de migrante esconde o conjunto de situações concretas e particulares, que definem sua identidade individual e social. Estas duas perspectivas conduzem às reflexões, segundo as quais, os fatores econômicos não são os únicos a serem levados em conta na análise da migração e dos migrantes. Seguindo estas idéias, após a análise deste processo de expropriação, resta-nos a abordagem da ressignificação social dos migrantes nos espaços de origem e de destino. Para levar a cabo esta idéia, o conceito de território migratório (Faret, 2001; Flores, 2006) é um instrumento eficaz para a compreensão dos dois espaços - de origem e de destino - não como pontos isolados, embora muito distantes geograficamente, porém como espaços que se acham unidos e próximos socialmente.

O processo de violência define a particularidade da reprodução do capitalismo nestas regiões, consideradas de fronteira agrícola, e fornece indicadores para o entendimento de duas situações: uma delas se reporta ao fato das empresas de São Paulo darem preferência a esta mão-de-obra, dado o fato de que os migrantes são provenientes de regiões onde predominam relações autoritárias, 
caracterizadas pelo poder dos donos de latifúndios, onde prevalecem relações de dominação que se assemelham à sujeição e ao escravismo; a segunda situação, derivada da primeira, se reporta ao fato de que estes trabalhadores são considerados pelas empresas como sendo mais dóceis, mais obedientes e aceitam com mais freqüência, as imposições das condições de trabalho, os salários baixos, a precariedade das condições de moradia do que os trabalhadores locais. Ademais, as diferenças regionais favorecem as empresas na medida em que elas incrementam a segmentação dos trabalhadores, segundo suas origens geográficas. Este dado dificulta a união política desta classe de trabalhadores, algo que se associa ao fraco papel desempenhado pelos sindicatos, que, muitas vezes, se associam aos patrões.

Feitas estas considerações, nosso esforço será no sentido de compreender estes territórios migratórios à luz das particularidades do caso concreto de migrantes temporários do Maranhão para os canaviais de S. Paulo, particularmente a região de Ribeirão Preto. Como vimos, ao longo de mais de meio século esta região é o lugar de destino de milhares de migrantes. Portanto, o que constatamos é uma migração permanentemente temporária, já que a grande maioria dos que migram regressam aos seus lugares de origem, enquanto outros se destinam a outras regiões, constituindo assim, outros ciclos migratórios - circulares, além dos pendulares - que se acham encadeados. Na realidade, há um eterno ir e vir, um eterno partir e chegar. Segundo a definição de territórios migratórios, é necessário levar em conta os espaços de origem e destino, além das dos lugares intermediários, como os de passagem e aqueles que servem como instalações temporárias no percurso da migração. O território migratório é um espaço organizado e significativo que mantém uma lógica própria (Faret, 2001).

É um espaço onde se criam novas formas de sociabilidade, se constroem redes, se elaboram estratégias, se encadeiam migrações locais, regionais e internacionais e se estabelecem os vínculos entre os agentes que possibilitam a inserção dos trabalhadores aos distintos mercados laborais. Neste sentido, a luta pelo controle do espaço é vital e é fonte para o desenvolvimento de novas identidades. (Flores, 2006, p. 1. Tradução de M. A. M. S.).

No caso de nosso estudo, os espaços de destino não são definitivos, mas temporários, pois no final da colheita da cana (que dura 8 meses), os trabalhadores partem. A maioria regressa após 4 meses, enquanto outros não. É interessante observar que contabilizam o tempo de migração a partir do número de safras e não a partir do número de vezes que migraram. Vale a pena ainda lembrar que a atividade laboral do corte da cana seleciona por si mesma os trabalhadores: homens jovens, entre 18 e 35 anos de idade, sadios e dotados de força física para suportar os altos índices de produtividade exigidos, algo que já ocasionou a morte por excesso de esforço de 20 trabalhadores entre 2004 e 2007. (Sobre os perfis dos trabalhadores mortos, consultar o site: www.pastoraldomigrante.org.br). A fim de captar as particularidades destes territórios migratórios permanentemente temporários, optamos por seguir os trajetos dos migrantes a partir de seus espaços de origem e, em seguida, os de destino.

\section{LUGARES DE ORIGEM, ESPAÇOS TRANSFORMADOS}

A pesquisa constatou que dentre os migrantes, há aqueles que sofreram definitivamente o processo de expropriação e vivem na periferia das cidades e também há os que ainda estão nas áreas rurais, na condição de moradores e parceiros, pagando renda em produto, proveniente da agricultura de alimentos e da castanha do babaçu, aos donos da terra, grandes latifundiários. Muitos destes últimos vivem numa situação de insegurança, dado o fato de que não têm condições para arcar com os preços do arame para cercar suas roças de alimentos, pois a prática dos proprietários para completar a expulsão dos camponeses é a do gado solto e da roça cercada.

Para os que vivem nas cidades, além do salário dos que migram a única fonte de rendimento é proveniente do trabalho das mulheres, enquanto quebradeiras de coco babaçu. No entanto, nas cidades, esta atividade está cada vez mais rara e difícil, pois as florestas estão muito distantes dos locais de moradia e como as mulheres não possuem nenhum meio de transporte necessitam per- 
correr longas distâncias a pé até os cocais. Trabalham o dia todo na coleta dos cocos e no final do dia os levam em sacos à cabeça para suas casas, onde são quebrados. Uma parte da produção é transformada em azeite para o consumo familiar e outra parte é vendida aos comerciantes locais ao preço de $\mathrm{R} \$ 0,80$ o $\mathrm{Kg}$. Em média conseguem quebrar de 5 a $7 \mathrm{Kg}$ de coco por dia, o que lhes rende de $\mathrm{R} \$ 4,00$ a $\mathrm{R} \$ 6,00$, valor insuficiente para a manutenção da família.

Nos bairros periféricos, habitados pelas famílias dos migrantes, o espaço urbano é uma continuidade do espaço rural. As casas são feitas de adobe e cobertas de folhas da palmeira do babaçu. Nos quintais, geralmente, há plantações de árvores frutíferas, como bananeiras, pinhas, mangueiras, além de mandioca, feijão e milho. Os fogões são a carvão da casca do coco babaçu. Há também criações de porcos, galinhas e ovelhas. As ruas são de terra, não há saneamento, porém, há luz elétrica. São muito freqüentadas pelas crianças e mulheres. A sociabilidade dos vizinhos e parentes ocorre nas ruas. Nas casas, há poucos homens, geralmente, os mais velhos. As mulheres casadas são chamadas viúvas de maridos vivos, em razão da ausência dos maridos. Quanto à atividade laboral, observamos que o trabalho feminino se reduz às tarefas domésticas e ao cuidado com as crianças e à quebra do coco.

Os sinais da distinção social aparecem na transformação das casas de adobe em alvenaria (tijolos). Inicialmente, há a troca da cobertura de folhas de palmeira pelas telhas de argila. Em seguida, iniciam a reconstrução das paredes e, por fim, a instalação de portas e janelas de madeira e de pisos cimentados. Além destas alterações, há a compra de aparelhos de televisão e de sons e, em alguns casos, a compra de motocicletas, sobretudo, pelos jovens solteiros. Estes objetos, comprados com o dinheiro advindo do trabalho dos migrantes, exercem uma enorme influência no imaginário do conjunto do grupo social e, ao mesmo tempo, são os ingredientes de mudanças de consumo e também de novos padrões de comportamento advindos da cultura migratória.

Estes objetos exercem uma verdadeira transfiguração dos jovens. A posse de uma motocicleta, do dinheiro para poderem freqüentar os bares da cidade com os amigos e as namoradas, o uso de camisetas com inscrições em inglês, de tênis, de óculos escuros, de boné, de bermudas, de relógio, tem, ao nível do simbólico, o poder de equipará-los aos jovens de outras camadas sociais da cidade. Portanto, tais mercadorias representam a construção de novas identidades individuais e sociais na medida em que novos padrões do gênero masculino são engendrados no bojo do processo migratório. Vários relatos revelam que o sonho de muitos jovens é migrar para "Ribeirão" (os canaviais paulistas) a fim de conseguirem tais mercadorias ou até mesmo serem aceitos no grupo daqueles que migram e têm dinheiro para o lazer, tal como pode ser visto no depoimento abaixo:

Isso aí é o seguinte: quando o cabra (referência ao migrante) chega lá..., eu analisava a minha vida mesmo. Os cabras chegavam, às vezes amigos meu mesmo que saíram e voltavam e passavam em casa e falavam: vamos jogar bola ali, vamos tomar uma cerveja ali, eu ficava um pouco acanhado, pois ficava com muita vergonha que os cabras tinham dinheiro e eu não tinha. Aí eles falam: não rapaz pode deixar comigo. Aí o cabra fica todo aflito. Aí o pessoal começa vir e você vem mesmo, não fica mesmo.

Sem embargo, o consumo não pode ser entendido como o determinante tout court. Ainda que a mercadoria seja o fim visualizado, ela representa a produção de novas identidades, na medida em que, além da distinção social, há, ao nível do imaginário, a realização do projeto de ascensão social, do êxito, da melhoria dos níveis de vida. Aos poucos, vai se constituindo uma cultura migratória que redefine as práticas sociais, os estilos de vida e as visões de mundo.

No que tange a casa, seu valor simbólico pode ser buscado em Bachelard.

A casa, na vida do homem, apaga as contingências e multiplica seus conselhos de continuidade. Sem ela, o homem seria um ser disperso. Ela mantém o homem através das tempestades do céu e das tempestades da vida. Ela é corpo e alma. ela é o primeiro mundo para o ser humano. Antes de ser 'jogado no mundo' (,..) o homem é colocado no berço da casa. E sempre em nossos sonhos, a casa é um grande berço” (Bachelard, 1998, pg. 26). 
Construir ou reconstruir a casa de tijolos e de telhas, segundo os padrões das classes sociais mais elevadas, representa para o migrante a consecução de um sonho de ascensão social e também um lugar seguro para si e para a família. Todos os entrevistados manifestaram o desejo de voltar ao Maranhão e lá construírem sua casa. Portanto, a casa no lugar de origem representa, ao fim e ao cabo, o desejo de retorno ao tempo e ao espaço e o fim da migração. É o ponto de chegada imaginado.

Aí eu comecei viajando para trabalhar no estado do Pará. Depois eu viajei para a capital de São Paulo. Aí lá ficou difícil encontrar serviço. Aí, da capital de São Paulo eu vim para o corte de cana. Só que já tinha trabalhado no corte de cana, já sabia como que era. Eu, desde 1983, que foi a primeira vez que eu saí, ainda era menor de idade. De lá para cá, todos os anos eu saio. Só que para morar mesmo é só no Maranhão. Se eu resolver mudar da minha cidade, eu mudo para outra cidade, mas dentro do Maranhão mesmo. Porque, em primeiro lugar, eu não troco o meu lugar por lugar de ninguém; nem no Brasil, nem fora. Primeiro lugar é lá no Maranhão. Eu trabalho e o meu suor tem que ficar é lá. Quando eu não quiser trabalhar mais aqui, eu vou trabalhar lá. É, a vida nossa é essa. (S. Nascimento, 2007).

As mercadorias imprimem novas relações sociais e também mudam a paisagem espacial e social. No entanto não há o desaparecimento do espaço social anterior. Os dois espaços, moderno e tradicional, coexistem e se redefinem, segundo o processo migratório. No tocante à sociabilidade feminina, observamos que apesar da distância geográfica, seus maridos e filhos ausentes se fazem presentes por meio das lembranças, das conversas, das notícias e também do tempo. Trata-se da redefinição da sociabilidade encontrada em várias situações: esperar aos domingos a chamada telefônica junto aos postos de telefonia da cidade, esperar pela volta do pai, em caso de nascimento de uma criança, não participar de festas na ausência dos maridos, ou ainda, casos de rupturas matrimoniais, em função da ausência de maridos, doação dos filhos às avós, em função de novos laços conjugais. No caso de jovens casais, muitas esposas acompanham os maridos até os locais de destino. Há também casos em que as mulheres partem com todos os filhos ou alguns deles, deixando os demais aos cuidados das avós. $\mathrm{O}$ fato de levar ou não os filhos está diretamente relacionado às condições financeiras da família. Estas situações concretas revelam que a migração exerce influências na estruturação interna das famílias e na redefinição dos papéis femininos e de muitas avós, que passam a se responsabilizar pela criação e educação dos netos. Ente esses camponeses é muito comum a prática da circulação das crianças entre parentes e vizinhos. Trata-se de uma estratégia para garantir a reprodução do grupo familiar, baseada nos costumes, em casos de dificuldades materiais ou de ausência dos genitores, Encontramos muitas crianças que possuíam além da mãe biológica, a adotiva, às vezes, convivendo no mesmo bairro. No caso dos avós, eles são beneficiários de um salário mínimo proveniente da aposentadoria, algo que, em alguns casos, é a única fonte de renda do grupo familiar extenso, envolvendo filhos e netos. Em outro trabalho (Silva, 2007), constatamos esta mesma situação em relação aos trabalhadores rurais de São Paulo.

Todavia, esta realidade não pode ser encarada sob a ótica da funcionalidade, como se não houvera conflitos. Constatamos que há muitos casos de rupturas matrimoniais, sem contar a ausência do pai no processo de educação dos filhos. Embora haja a redefinição dos papéis femininos, a separação física e social imprime sofrimentos, que acabam afetando a saúde física e emocional tanto dos homens quanto das mulheres, muitas das quais ficam enfermas, segundo relatos. A migração divide a vida das pessoas no tempo e no espaço. Esta é a lógica deste território migratório: ao mesmo tempo em que é o determinante do conjunto destas vidas, imprimindo-lhes o elo unificador entre os que partem e os que ficam, reproduz permanentemente a transitoriedade e a divisão espacial e social. São vidas transitórias, marcadas pelo eterno partir e chegar.

Os espaços de origem são também os lugares onde se engendra o mercado de trabalho para as empresas capitalistas de São Paulo. Apesar da distância geográfica, as empresas controlam este mercado por meio dos gatos (enganchadores). Estes mercadores de mão-de-obra pertencem á comunidade de origem dos migrantes, são, em geral, antigos trabalhadores das empresas coop- 
tados por elas e considerados pessoas de sua confiança. Os gatos realizam a primeira seleção dos trabalhadores: escolhem os melhores, isto é, os mais jovens, dotados de força física e aqueles que não são encrenqueiros, isto é, os que não abusam de bebidas alcoólicas, os mais obedientes, que, seguramente não protestarão contra as condições de trabalho e não participarão de movimentos reivindicatórios. Ademais da força física, estes atributos comportamentais são importantes nesta seleção, pautada por critérios políticos e ideológicos. Este fato é importante para as empresas na medida em que continuarão com a prática do sistema de superexploração, responsável pelos gigantescos lucros. O gato exerce também outras funções: ele representa o elo de ligação entre os trabalhadores e as empresas, e, em virtude de seu papel contraditório, ele, ao mesmo tempo em que se afirma enquanto representante dos trabalhadores, ele defende os interesses das empresas. Neste jogo contraditório, ele acaba se revestindo com a máscara de protetor dos trabalhadores, um igual, que leva notícias para as famílias, que pode ajudar nos casos de doença, que empresta dinheiro para a viagem, feita em ônibus fretado por ele, que consegue o emprego e a moradia nos locais de destino, segundo seu conhecimento e experiência. Enfim, mantém com os trabalhadores a relação assistencialista, paternalista, mistificadora e ratificadora da exploração vigente. (Silva, 1999). Como pertence ao mesmo espaço de origem dos trabalhadores, exerce sobre eles o controle ideológico sobre suas condutas, até mesmo no período do não trabalho (de dezembro a março, na entressafra da cana). É por meio deste controle que ele define os "bons e os "maus", quem partirá e quem ficará.

Durante a pesquisa de campo, constatamos a presença de uma rede de aliciamento de trabalhadores desta região para várias partes do país, além de São Paulo. Desta rede fazem parte os gatos e pessoas de outros estados do país, que se escondem das fiscalizações da polícia sob a capa de agenciadores de viagem, cumprindo apenas a função de vendedores de passagens de ônibus. Tais aliciadores cobram um preço mais elevado das passagens pagas pelos trabalhadores além de $\mathrm{R} \$ 60,00$ da empresa por cada pessoa arregimentada. Trata-se de uma rede de exploração que está vinculada ao sistema de precarização e flexibilidade do trabalho imposto pelas grandes empresas. Muitos dos trabalhadores aliciados são transformados em escravos nas regiões norte, centro-oeste, inclusive no Paraná e Santa Catarina (sul) e Ceará (nordeste), segundo denúncias da Comissão Pastoral da Terra e da Campanha Nacional de Combate ao Trabalho Escravo. Segundo a CPT (Comissão pastoral da Terra), os trabalhadores escravizados em 2006 no país foram 6930, dos quais 3633 foram libertados. A violência se caracterizou pelas ameaças de morte, assassinatos, agressões, danos, intimidações e humilhações (CPT, 2006, p.129 -136). A escravidão se constitui na particularidade histórica da reprodução do capitalismo na agricultura brasileira e está intimamente ligada ao processo migratório interno. Este dado é mais um ingrediente para a compreensão dos territórios migratórios, enquanto processos sociais contraditórios e não funcionais, que possuem características próprias, segundo as distintas realidades históricas.

\section{LUGARES DE DESTINO, ESPAÇOS FECHADOS E CONTROLADOS}

Segundo a análise acima, os migrantes maranhenses se dirigem às regiões canavieiras do estado de S. Paulo em ônibus fretado pelos gatos. São levados, após três dias e três noites de viagem, aos barracos (moradias precárias) das periferias das pequenas cidades ou para os alojamentos das empresas no interior dos canaviais, onde o controle é muito grande e é exercido diretamente pelos gatos, que instala um pequeno comércio onde vende produtos a preços mais elevados aos trabalhadores. Em razão deste controle, o acesso a estes locais só ocorre com permissão das empresas. Os trabalhadores aí vivem isolados e vigiados. Em função do grande número de pessoas num mesmo espaço, já houve ocorrência de doenças e epidemias. A ocorrência de epidemia de sarampo entre trabalhadores rurais alojados no interior dos canaviais na região de Ribeirão Preto foi analisada como doença ocorrida em função das condições sociais destes trabalhadores, pois o sarampo não é uma doença comum na fase adulta. Foram detectados 153 casos da doença num total de 3705 trabalhadores de uma usina de cana-de-açúcar e álcool. (Pontes, 1990). 
Quanto aos que se dirigem às cidades, em virtude do preço alto dos aluguéis, são obrigados a morar em grande número em pequenos cômodos com tanque de lavar roupas e sala de banho coletivo. Estas moradias são insalubres e alvo de constante fiscalização sanitária. Em função das 20 mortes por excesso de trabalho ocorridas no período de 2004 a 2007, tem havido fiscalização nestas moradias por parte da Vigilância Sanitária. As principais deficiências são: existência de poucos banheiros para um grande número de homens, fogões nos quartos de dormir e muitas pessoas em pequenos cômodos, além da precariedade das construções. No que concerne à sociabilidade dos migrantes, observamos que eles ficam praticamente isolados do conjunto da cidade. São vistos como pessoas de "fora", como estrangeiros no próprio país. O contato com os moradores se restringe aos agentes da Pastoral do Migrante, aos donos de supermercados, bares e proprietários dos barracos, tal como aparece no depoimento seguinte:

Quando voltamos ao Maranhão é uma emoção, tanto da gente, como do pai e da mãe, das irmãs, dos irmãos, dos vizinhos. Porque você se sente em casa. Aí você chega em casa, o povo é mais aberto. Aqui é o seguinte: se você for até a casa do maranhense, é bem diferente. Acontece que, às vezes, você sai para ir até a casa deles, eles estão trabalhando. Quando eles vêm visitar a gente, nós estamos trabalhando. Aí fica cada um no seu barraco. Agora, quando você chega lá, uns falam: ah, eu vou até a casa de um primo, eu vou até a casa de um compadre, eu vou até a casa de uma namorada, eu vou até a casa de uma menina, eu vou à uma festa etc. Aqui fica cada um no seu barraco. Quase não saímos. Lá é bom demais. Os meninos falam: rapaz amanhã tem uma festa na casa de fulano de tal, e isso é muito divertido, é bom demais. Aqui não, é só da cana para casa, e de casa para a cana. É por que eu falo: aqui nós só viemos para trabalhar. Aqui o maranhense só vem para trabalhar (...). Aqui nós vimos para trabalhar..., é para trabalhar... P. Nascimento, como que é o seu dia de folga (descanso)?

R. Dia de folga é o seguinte: você trabalha cinco (5) dias e folga um. É..., trabalha cinco (5) dias e folga um. Hoje..., hoje é domingo. Então nós vamos folgar no próximo sábado. Aí, no dia de hoje, nós já lavamos a casa, lavamos as roupas. Sem ser as roupas de serviço, porque as roupas de serviço você tem que lavar todos os dias. Então é assim nosso dia de folga. Desse jeito como você chegou, bem sentado nessas garrafas, pois nem sofá nós não temos. O dono da casa não deixou nada. Aí nós compramos essa televisão e esse DVD, e ficamos assistindo e quando chegar amanhã, para nós começarmos de novo; e no próximo final de semana é a mesma coisa. E é só isso. Mas esse negócio de festa, folia... essas coisas aí, aqui conosco não tem isso.

P. Você tem relação com as pessoas daqui da cidade (Pradópolis)?

R. Não! Aqui nós não temos nenhum entrosamento com a pessoal daqui. O entrosamento que temos aqui é só com o pessoal da Igreja. Como o rapaz ali e a moça que você citou. Eles são voluntários que andam nos barracos da gente (membros da Pastoral do Migrante de Pradópolis); são essas pessoas que andam nos barracos da gente. Mas o pessoal daqui, não vem. Só se o aluguel estiver atrasado; aí o dono do barraco vem mesmo. Mas o pessoal daqui, não vem. Aí o dia-a-dia nosso é isso mesmo.

P. E nas ruas, como que é?

R. É nas ruas, às vezes você encontra com o pessoal. Mas é como eu lhe falei, ninguém aqui gosta de rua. Têm uns que vão tomar um guaraná (refrigerante). Mas aqui ninguém bebe, nem fuma. Eu mesmo não bebo, não fumo.

P. Quando você sai, que está andando pelas ruas, como que as pessoas de Pradópolis vêem você?

R. Ah, eles vêem a gente com outros olhos. Não como na terra da gente. Na terra da gente, você passa por uma pessoa conhecida é outra coisa; mesmo que ela não é conhecida, sempre é diferente. Aqui mesmo, se ou saio de casa para ir dar uma volta na rua, tenho até vergonha de falar com o pessoal daqui. Que o pessoal é diferente. Aqui mesmo morava um rapaz, que foi embora, porque não entendia nada do pessoal daqui, inclusivo até a fala é diferente.. Aí eu pelo ou menos acho diferente o pessoal daqui com o pessoal nosso. E somos todos brasileiros... somos todos brasileiros. Só que eles são de um estado e nós somos de outro. O pessoal que eu me identifico mesmo é com o piauiense, cearense, catarinense etc. Mas cada qual no seu lugar. Eu falo assim, o modo de conversar, pela fala, o piauiense é a mesma coisa do maranhense. Agora, quem está no estado do Pará é a mesma coisa de estar no estado de São Paulo. Porque o paraense também não trabalho no pesado. Porque eles acham que nós que trabalhamos 
no pesado, não somos pessoas de nada. Eles consideram a gente como pessoas de nada. Pessoas de nada. Pessoas de nada... Agora mesmo você chegou aqui, mas tem gente que pensa que cortador de cana é um nada. Porque eles aqui não consideram ninguém não; porque acham que cortador de cana é diferente. Porque eles pensam que nós, lá no nosso estado somos diferentes. Mas tem gente aqui que não gosta de nós mesmo, quer que seja, mas pode chegar lá na minha terra e pensar que sou eu é quem não posso gostar dele. Aí eu passo passar por ele e pensar outra coisa. Pois é, o pessoal daqui é diferente. Não todos. Tem pessoas aí que são boas, como esses que você citou.

P. Você falou que não gosta de bailes, forrós (dança). Nos dias de folga, para o seu divertimento, além de assistir TV, DVD, o que mais que você faz para se divertir?

R. É..., o maior divertimento nosso aqui é a bola (jogo de futebol). Porque é o seguinte: hoje têm duas turmas que estão folgando, aí eles apostam. Aí têm aqueles que jogam, e outros que vão para o campo de futebol. Agora eu mesmo, no dia da minha folga fico em casa mesmo. Não vou para lugar nenhum. Muitas vezes vou ao mercado; vou na parte da manhã, porque na parte da tarde o mercado já fechou; compro carne para levar amanhã, porque se eu for na parte da tarde, não tem jeito de levar carne para comer amanhã. Aí tem vez que eu vou para Ribeirão, no dia de folga, para fazer alguma compra.

O depoimento demonstra que o tempo de trabalho é o que predomina. Não há lazer, pois o dia do descanso é utilizado para a compra de alimentos, lavagem da roupa e o repouso das energias. A sociabilidade é fragmentada pela ausência de comunicação com as pessoas da cidade que os vêem como diferentes (são negros, descendentes de escravos e de quilombolas), e também pelos demais maranhenses que habitam em outros barracos, pois os dias de descanso não são os mesmos para todos. As empresas impõem o sistema 5 por 1, isto é, cinco dias de trabalho e um de descanso, segundo as diferentes turmas de trabalhadores, impedindo assim que os domingos sejam dedicados coletivamente ao lazer, o que restringe a sociabilidade tão-somente ao trabalho. O tempo é reduzido ao trabalho e controlado pelas empresas. A fim de aumentarem os lucros e manterem a produção em níveis elevados, o tempo de trabalho nas usinas é de 24 horas diárias, inclusive na agricultura, cujas atividades noturnas envolvem o corte mecanizado da cana, o transporte em caminhões, o que impõe a muitos trabalhadores o trabalho noturno, sem contar que a cana cortada manualmente é queimada na noite anterior, atividade de extremos riscos e com registros de muitos acidentes com mortes. Ainda mais. Muitas usinas, com o mesmo intuito pagam em dobro o preço da tonelada de cana cortada nos dias de descanso, o que contribui para aumentar o desgaste físico dos trabalhadores, pois os salários são pagos por produção, ou seja, por tonelada de cana cortada, ao preço de $\mathrm{R} \$ 2,40(1 \mathrm{U} \$=\mathrm{R} \$ 1,96)$.

A segmentação dos trabalhadores ocorre tanto no local de trabalho, quanto nos bairros periféricos das pequenas cidades da região de Ribeirão Preto. Tal segmentação ocorre em razão das divisões étnico/raciais, segundo os locais de origem dos migrantes. No que tange aos maranhenses, eles são negros, ao passo que aqueles de outros estados do nordeste, geralmente, são pardos, isto é, descendentes da miscigenação de índios, negros e brancos (os portugueses). No Brasil, a questão étnico/racial é camuflada pela ideologia dominante, segundo a qual, a mistura de muitas raças impediu a produção da discriminação étnico/racial, algo que não corresponde à realidade existente, sobretudo no estado de S. Paulo, cuja imigração de brancos europeus nos finais do século XIX e início do século XX, foi uma das respostas à ideologia do branqueamento do povo brasileiro, produzida pelas classes dominantes.

Estas condições histórico-sociais ao serem apropriadas pelas empresas capitalistas reforçam a segmentação e transformam as diferenças da cor da pele em desigualdades e hierarquizações. Desta sorte, os maranhenses são considerados pelos baianos como maus trabalhadores, preguiçosos e incapazes de conseguir os níveis de produtividade do trabalho exigidos pelas empresas. Outras divisões e discriminações se reproduzem no interior de outros grupos de migrantes e também em relação aos trabalhadores locais (os chamados bóias-frias), considerados paulistas, embora boa parte deles seja descendente de migrantes, inclusive de negros. Esta realidade, além de invisível, é silenciada tanto pelos empregadores, quanto pelo conjunto dos trabalhadores e habitantes das cidades. Desvendar as divisões espaciais (invisíveis), segundo o lugar de origem dos migrantes e aquele 
dos trabalhadores locais, é necessário para a compreensão da dinâmica dos territórios migratórios, enquanto lugares simbólicos, definidos por representações sociais dos diferentes grupos reunidos no mesmo espaço geográfico. (Melo 2007; Vettorassi, 2006).

No que tange às mulheres, que acompanham seus maridos com ou sem filhos, também se observam além destas divisões étnico/raciais, as de gênero. Suas funções são estritamente ligadas ao trabalho doméstico. Vivem nos cômodos alugados, raramente saem às ruas e usam seu tempo segundo o tempo de trabalho dos maridos. Preparam-lhes a comida ainda pela madrugada, lavam suas roupas e os esperam no final do dia, quando regressam do trabalho. Algumas delas participam de atividades como aprendizagem de corte e costura, crochê, bordados, sob a orientação da Pastoral do Migrante. A sociabilidade delas se restringe ao convívio com outras mulheres maranhenses e, do mesmo modo que os homens consideram o lugar de destino como passagem, algo temporário em suas vidas e nutrem a esperança do retorno para seus lugares de origem. Da mesma forma que as mulheres que não partem, elas esperam a chegada do domingo, quando telefonarão para ter notícias dos que ficaram, sobretudo, dos filhos deixados para trás. A imagem do retorno é gerada pelo desejo, pela vontade, portanto, esta imagem também é um elemento constitutivo desta identidade.

No entanto, pode-se retornar ao espaço, mas não ao tempo. O tempo é outro. As roças de subsistência estão em vias de desaparecimento, as atividades extrativistas relacionadas ao coco babaçu estão cada vez mais rarefeitas, muitos parentes e amigos já se foram. Considerando que espaço-tempo formam uma simbiose, conclui-se que o espaço também não é mais o mesmo. $\mathrm{O}$ retorno se faz em busca de algo imaginado.

A presença nesta vida e no mundo que a carrega é como uma presença distraída, uma presença ausente, uma presença distanciada; em contraste, a outra vida ausente ou a vida que se consagra à ausência, aos lugares longínquos e aos tempos passados da ausência, é como uma vida que a evocação sonhadora torna presente, mas de uma presença fantasmagórica, totalmente irreal, onírica, que se desenrola paralelamente á vida ativa e cotidiana. (Sayad, 2000, pg. 20).

A autora francesa Michèle Bertrand possui uma reflexão extremamente significativa sobre o imaginário, a qual far-se-á uso para interpretar o conteúdo dos depoimentos relacionados ao lugar de origem e, sobretudo, da saudade que sentem.

A imaginação não é apenas uma construção da mente, é também o meio pelo qual os homens agem sobre eles mesmos, uma ação auto-plástica que adquire tanto mais importância quando á ação aloplástica (transformadora da realidade externa) se revela impossível. Com efeito, quando os homens não conseguem mudar o mundo... é toda uma configuração imaginária que se transforma e tenta se adequar ás aspirações inconscientes. (Bertrand, 1989, pg. 29).

(...) mãe, agora eu vou mesmo. Ela falou: filho você vai me deixar? Falei: mãe, eu vou mas eu volto, com fé em Deus! Sempre vou ligar para a senhora. Se precisar de um dinheirinho, e eu tiver no momento, posso mandar para você. Aí eu saí de lá, ela ficou chorando..., chorando. Eu falei: mãe eu vou, mas eu volto. É muita emoção da gente. Às vezes a gente esta aqui, fica pensando nas pessoas lá no Maranhão, dos amigos da gente, dos pais, eu mesmo tem dia aqui que fico assim... pensando nos pais, e dá uma vontade de chorar. Aí eu tenho que segurar para não chorar. É isso mesmo, minha vontade era essa, esse sonho eu realizei. Tenho fé em Deus de chegar ao final da safra tudo em Paz, e chegar lá com alguma coisinha.

Impossibilitados de transformar o mundo, de deter o processo da migração forçada, a ação dos migrantes e daqueles que ficam pode ser percebida por intermédio de várias formas: ações coletivas e individuais de resistência, conformismo, imagens de rostos sofridos, de suas falas e também de seus silêncios. Ao descreverem sobre a própria história se transformam em narradores e lembradores que sentem saudades. Narrativas não de um passado longínquo, mas de um passado-presente, vivido em dois espaços e dois mundos. Espaços, mundos e tempos unem-se quando os narradores 
acham-se separados, e, ao contrário, separam-se quando os narradores se unem. Esta é a dialética dos territórios migratórios. Quando voltam aos seus lugares de origem, esperam o momento da partida, pois lá não podem ficar.

Outro dado importante sobre a sociabilidade nos lugares de destino se reporta à sexualidade. Em se tratando de homens jovens que migram, na sua maioria sozinhos, permanecendo oito meses sem as famílias, vivendo isolados nos alojamentos no interior dos canaviais ou nos barracos das periferias urbanas, esta questão aparece nos depoimentos. Os contatos sexuais ocorrem geralmente em locais de prostituição, situação que, em algumas cidades, já tem sido denunciada pela imprensa. Recente reportagem sobre a prostituição, inclusive de adolescentes, como resultado da expansão da cana-de-açúcar na cidade de Delta, no estado de Minas Gerais, é um dos sinais do processo de acumulação das empresas ligadas a esta atividade, cujas características são a concentração de terra e de renda, de um lado, e do outro, a concentração da miséria. "Apelidados de "maranhenses", os forasteiros, amontoados em barracas e favelas, transformaram o município num verdadeiro "formigueiro humano", nos moldes do garimpo de Serra Pelada, que atraiu, na década de 1980, milhares de forasteiros ao Sul do Pará. A exemplo de áreas de garimpo, Delta não tem nenhum hotel e em mesmo um delegado residente. Em compensação, passou abrigar centenas de prostitutas, espalhadas por 27 boates e casas de prostituição".(Estado de Minas, 14 de maio de 2007).

Nos locais de origem também já a parecem os resultados desta realidade: doenças sexualmente transmissíveis (DSTs), como sífilis e AIDS (SIDA). O depoimento seguinte revela que o contato sexual com as mulheres dos locais de origem é raro, salvo em locais de prostituição, surgidos no contexto das migrações.

Aqui é difícil com as meninas (as jovens). As meninas passam aí, às vezes, a gente está sentado lá fora, e elas nem olham pra gente. No Maranhão é bem mais fácil. Você chega em um lugar, a mulher passa por você e olha; você chama ela, logo ela vem. Aqui não é assim.

A fim de completar a análise sobre os territórios migratórios de destino, restam-nos algumas reflexões sobre os espaços laborais, chamados eitos (palavra advinda da época da escravidão) dos canaviais. Como dissemos acima, a atividade da colheita da cana exige grande esforço físico em razão do aumento das exigências dos níveis de produtividade, atualmente, em torno de 12 a 15 toneladas de cana cortada ao dia. Na década de 1980, este números eram de 6 a 8; na década seguinte passou para 8 a 10 toneladas Antes do corte, há a queima da palha da cana, algo que traz sérios problemas de saúde aos trabalhadores - e às populações locais - em razão da fuligem que contém resíduos de agrotóxicos e é aspirada diretamente no momento do corte. A isto, soma-se o calor excessivo, chegando, em algumas regiões a mais de 40 graus. A repetição constante de golpes de facão - para cada dez toneladas, são 10 mil golpes -, a curvatura do corpo e o ritmo excessivo do trabalho causam muitas dores, provocando câimbras, em virtude da sudorese que leva à perda de potássio. Este ambiente de superexploração do trabalho foi o responsável por 20 mortes, ocorridas entre 2004 e 2007 por excesso de esforço físico. A maioria dos mortos era migrante e suas idades variavam entre 20 e 35 anos. Ademais das mortes, constatamos que a vida útil de um cortador de cana é inferior a 15 anos, sendo que a dos negros na época da escravidão variava de 15 a 20 anos. (Silva, 2005). Estes altos níveis de exploração garantem os gigantescos lucros das empresas nacionais e internacionais do setor sucroalcooleiro concentradas na região de Ribeirão Preto, cuja expansão se verifica cada vez mais em outras áreas do estado e do país para a produção do etanol, a fim de garantir a demanda dos mercados externos, principalmente dos EUA. No ano de 2006, o maior grupo empresarial do setor sucroalcooleiro do país, COSAN, que reúne capitais da França, EUA e Brasil, registrou lucros de mais de dois bilhões de reais.

O depoimento de um migrante maranhense revela as condições de trabalho existentes nos canaviais paulistas.

P. Você falou que o serviço no corte de cana é duro. Você poderia falar um pouco mais das condições de trabalho? 
R. Rapaz, o serviço de cana não é para a gente. Para nós humanos? Não! Rapaz, nós somos feitos de carne e osso. Você vê o cabra (expressão regional que significa o homem) cortar 300, 500 metros de cana em um eito de cana, e o feitor em cima da gente, para fazer bem feito, cortar bem feitinho. Aí, tem vez que o cabra tem vontade de até brigar com o feitor. Às vezes, o cabra está ruim, porque o cara fica humilhado mesmo. É..., no corte de cana não é fácil de trabalhar. Hoje mesmo eu estava ouvindo aí um comentário sobre a escravidão. Só que, se você olhar bem, a escravidão mesmo está longe de acabar. Hoje estava passando aí sobre o fim da escravidão, mas se você for analisar mesmo, ela está longe demais de acabar. O que pode ter acabado assim..., porque naquele tempo, você trabalhava de graça, apanhava. Pode ter acabado isso daí. Mas a escravidão mesmo não acabou.... Não acabou...!

P. Você acha que há uma pressão no eito da cana? Como é?

R. Ave Maria... Risos... Essa pressão. Você tem que levar três ruas de cana, tirar as pontas, toco dentro do chão. Se o feitor, ver pelo menos um toquinho fora, é "gancho" (significa ser suspenso do trabalho)... é "suspensão"... E você não pode responder. Se você responder é pior. Que se você responder, ele deixa você três dias de "gancho"; é pior para você. Você está trabalhando no meio da cana, você está suado; todo melado; a cana ruim; sol quente, e o feitor gritando nos seus ouvidos; aí se você for responder. Suponhamos que no dia de amanhã você não vai trabalhar, você passa três dias em casa, e você devendo aluguel, água, luz, tem que comprar comida, aí seu pagamento vem desse tamanho (afirmando se pouco) que é humilhação para o cabra. Você acha que ainda não é a escravidão? É sim! O feitor quer que a gente trabalha direito; disse ele é porque a usina exige. Mas ele faz isso mesmo para ver se o trabalhador fala alguma coisa, para suspender o cortador de cana.

Além do desgaste físico, das doenças respiratórias, câncer de pele e de pulmão, em virtude do sol e dos agrotóxicos, do controle exercido no ato do trabalho pelos feitores -conforme o relato acima -, há muitas mortes em função de acidentes de trabalho, e de transportes, em razão da precariedade dos ônibus que levam os trabalhadores até os canaviais. Relatório da Delegacia Regional do Trabalho em São Paulo registrou 416 mortes em 2005 no setor sucroalcooleiro, a maioria por acidentes. (Ata das reuniões da Fundacentro e representações sindicais do setor sucroalcooleiro em 2006).

A existência destas condições de trabalho marcadas pela superexploração, pela precariedade e pelo desrespeito e violência aos direitos humanos do trabalho está aliada às migrações internas, resultantes da formação de um enorme exército de trabalhadores, expropriados da condição de camponeses em virtude do avanço dos grandes capitais em várias regiões de fronteira agrícola do país. (Silva et al ,2006).O conceito de territórios migratórios nos permitiu a compreensão desta realidade a partir de sua dinâmica contraditória, capaz de captar a ação dos sujeitos nela envolvidos e também as particularidades históricas do processo de acumulação dos capitais aplicados na produção de etanol desta região, como fonte de energia, para os mercados externos.

\section{CONSIDERAÇÕES FINAIS}

Com base nos dados de uma pesquisa sobre camponeses do Maranhão (meio norte do Brasil), expropriados de suas terras por meio da violência de grandes empresas, que se transformaram em migrantes para os canaviais do estado de São Paulo, onde se concentram as maiores usinas de açúcar e álcool (etanol) do país, mostramos que se trata de uma mobilidade essencialmente masculina, sobretudo de jovens, o que corresponde à produção de novas configurações familiares - pois os membros das famílias se dividem no espaço e no tempo -.

Inicialmente, analisamos as condições históricas das duas regiões responsáveis por este processo migratório, e, em seguida, procuramos, a partir do conceito de territórios migratórios compreender o significado desta migração permanentemente temporária, já que os sujeitos sociais não podem permanecer nem no lugar de origem e nem no lugar de destino. São eternos caminhantes, cujas vidas transitam por diferentes espaços, sem se fixarem em nenhum deles. Segundo Faret (2003) e Flores (2006 e 2007), os territórios migratórios possuem uma lógica própria, na medida em que espaços geograficamente distantes são unidos pelas práticas e ressignificações dos migrantes por intermédio de redes sociais nos distintos lugares por onde transitam.

Revista da ANPEGE, v. 7, n. 1, número especial, p. 161-178, out. 2011. 
Esta investigação revelou que os territórios de origem e de destino se acham articulados pelo mercado laboral masculino, responsável pelos altos lucros das empresas agroexportadoras de São Paulo. No entanto esta articulação não é meramente funcional, ou seja, estes territórios não são meramente complementares entre si. As novas dinâmicas produzidas demonstram que se trata de uma unidade contraditória, marcada por muitas rupturas, perdas, doenças, mortes e também pela produção de novas representações sociais, novos sentidos, novas estratégias, originados do campo simbólico e imaginário. Todos os projetos de vida tanto dos que ficam como dos que partem se assentam sobre o desejo de retorno definitivo para o lugar de origem. Para isso, desejam construir a casa de tijolos e assegurar melhores condições para que os filhos não precisem migrar, enfim, desejam a ascensão social. Apesar da superexploração da força de trabalho, da precariedade das condições de moradia, das discriminações étnico/raciais nos lugares de destino, das dificuldades encontradas em razão da separação das famílias, os sujeitos envolvidos neste processo social não são vítimas passivas. Criam estratégias que visam a diminuir as perdas sofridas, e, em muitos casos, apesar da distância geográfica, os vínculos sociais e familiares são redefinidos e reforçados e pequenas resistências são produzidas.

Durante a pesquisa, constatamos que um dos gatos da cidade de Timbiras possui uma loja que vende passagens de ônibus para o estado de São Paulo, principalmente, para a região de Ribeirão Preto, durante todo o período da colheita da cana ( 8 meses ao ano). Este fato chamou nossa atenção, pois, até então, acreditávamos que houvera dois momentos de trânsito dos migrantes: um no início da safra (mês de abril) e outro no final (novembro). Inquirido sobre esta questão, ele nos informou que durante todo o tempo há trabalhadores que vêm e outros que voltam, sem contar a presença de muitas mulheres, cujos maridos, após receberem o primeiro salário, lhes enviam o dinheiro para a compra da passagem. Encontramos uma mulher de 68 anos de idade, que viajaria no mês de maio para cozinhar e lavar as roupas dos quatro netos migrantes. Sua intenção era permanecer até o final da safra. Esta mulher nos disse também que, além do trabalho, seu desejo era ficar junto dos netos, já que a mãe deles havia morrido e ela os criara desde quando eram pequenos. No caso dos trabalhadores que regressam antes da safra, os motivos variam: muitos não suportam a dureza do trabalho; outros não são selecionados pelas usinas em razão de não conseguirem manter os altos níveis de produtividade no corte da cana; outros adoecem; outros em virtude de acidentes de trabalho não podem mais trabalhar; outros são despedidos por não acatarem as normas de controle no ato do trabalho; outros partem em busca de outros lugares de trabalho; outros ainda, atraídos pelas promessas enganosas de aliciadores, ao não encontrarem trabalho, são "expatriados" pelas prefeituras locais em ônibus que os levam de volta aos seus lugares de origem. Na safra atual, a “expatriação de maranhenses ocorreu em várias cidades desta região: Guariba (43); Dumont (100), Dobrada (250), segundo informações da Pastoral do Migrante. Após a viagem de mais de três dias e três noites, estes trabalhadores são "despejados" nestas cidades. A maioria não possui dinheiro para a compra da passagem de volta, para a compra de alimentos e nem para o aluguel dos barracos. Recebem alimentação das prefeituras e em seguida são "extraditados", conforme o título da reportagem; Prefeituras "extraditam" bóias-frias sem emprego(Folha de S. Paulo, ribeirão, 22 de maio de 2007, C1).

Tais situações definem os contornos da mobilidade destes múltiplos territórios migratórios que são permanentemente temporários. São vidas marcadas pela incerteza, transitoriedade e também pelo desejo de conseguirem realizar o projeto de distinção social, quer seja por meio da compra de algumas mercadorias do mundo capitalista, quer seja pelo cumprimento dos padrões comportamentais relativos aos gêneros. Os homens jovens desejam o sucesso, "subir na vida", por meio do trabalho; aqueles que possuem filhos querem dar-lhes condições para que possam estudar e terem melhores oportunidades laborais futuras. Cumprem, assim, os papéis de provedores responsáveis e de chefes de família. As mulheres, enquanto mães ou avós, ao cuidarem da prole, ratificam seus papéis reprodutivos, enquanto muitas outras da região de destino se transformam em prostitutas para atender ao mercado sexual criado pela migração. Desta sorte, homens e mulheres de lá e de 
cá vivem a dialética do transitório e sonham com o permanente. É esta engrenagem que os move nestes territórios permanentemente temporários.

\section{REFERÊNCIAS BIBLIOGRÁFICAS}

ANTUNES, M. As guardiãs da floresta do babaçu e o tortuoso caminho do empoderamento. In: WOORTMANN, E.;HEREDIA, B.; MENASCHE, R. (orgs.). Margarida Alves. Coletânea sobre estudos rurais e gênero. Brasília: NEAD, MDA, IICA, 2006, p.123-149.

BACHELARD, G. La poétique de l'espace. Paris: PUF, 7a edição, 1998.

BERTRAND, M. O mundo clivado - a crença e o imaginário. In: SILVEIRA, P.; DORAY, B. (org). Elementos para uma teoria marxista da subjetividade. São Paulo: Vértice, 1989, pg.15-40.

CARNEIRO, S. M. Deslocamento temporário e superexploração dos trabalhadores de Timbiras em empresas do complexo sucroalcooleiro do estado de São Paulo. Conferência realizada no Fórum Estadual de Combate ao Trabalho Escravo, promovido pela Delegacia Regional do Trabalho (DRT-MA), no dia 19 de ago. de 2005, na cidade Codó/MA.

COMISSÃO PASTORAL DA TERRA (CPT). Conflitos no campo. Goiânia: CPT Nacional, Brasil, 2006. FARET, L. Mobilité spaciale et territorialité. De la diversité de formes de construction du rapport aux lieux. Séminaire PRISMA. Toulouse, 10-11 de maio, 2001.

FLORES, S. M. L. Circulación terrritorial y encadenamientos migratorios de los jornaleros agrícolas en el Noroeste del México. Teoria e pesquisa, n. 49, jul/dez, 2006. p. 13-34.

FLORES, S. M. L. Control del espacio y territorialidad en las migraciones rurales. Trabalho apresentado no GT 4: Nuevas migraciones y empleo rural en América Latina no VII Congreso de Alasru. Anais...Quito, 20-25 de noviembre de 2006 (Versão eletrônica).

MARTINS, J. S. Expropriação e violência. A questão política no campo. São Paulo: Hucitec, 1982.

MARTINS, J.S. Migrações temporárias: problema para quem? Travessia, CEM, V. 1, p. 5-8, maio-ago., 1988. MELO, B. M. Memória, migração e territorialidade. O trabalhador rural nordestino na Ibaté Paulista. Relatório apresentado para o exame de qualificação de mestrado. PPG/Geografia/UNESP/PP, 2007.

MOTTA, A . C. R.; QUINTEIRO, M. C. Repercussões do Proálcool no comportamento migratório do estado de São Paulo: o caso de Ribeirão Preto. Informe Demográfico (São Paulo), Fundação SEADE, n. 10, 1983. (Relatório de Pesquisa).

PONTES, R. J. S. Sarampo em trabalhadores rurais: ensaio metodológico de epidemiologia social. Revista de Saúde Pública v. 24, n. 4, ago, 1990.

SADER, R. Migração e violência - o caso da pré-amazônia Maranhense. Terra Livre, N.6, p. 65-76, 1991.

SAYAD, A. O retorno. Travessia, n. especial. São Paulo, janeiro 2000.

SILVA, M. A. M. As Andorinhas. Nem cá. Nem lá. Vídeo. VHS, UNESP/Araraquara, 1991.

SILVA, M. A. M. Errantes do fim do século. São Paulo: Edunesp, 1999.

SILVA, M. A. M. A face oculta do trabalho: migrantes temporários nas usinas canavieiras de São Paulo. Revista Latinoamericana de Estudios del Trabajo (RELET), Año 10, N. 17, 2005. p. 31-54.

SILVA, M. A. M. et al. Do Karoshi no Japão à birola no Brasil. As faces do capitalismo mundializado. Nera, ano 9, n. 8, jan/jul 2006.

SILVA, M. A . M. et al. A família tal como ela é nos desenhos das crianças. Ruris, v. 1, n. 1, 2007. p. 105-156. VETTORASSI, A. Espaços divididos e silenciados. Dissertação de mestrado. PPG/Ciências Sociais/ UFSCar, 2006. 